\title{
Students Perceptions of the Educational Environment: A Cross-Sectional Study from a Moroccan Medical University
}

ISSN: 2639-0612

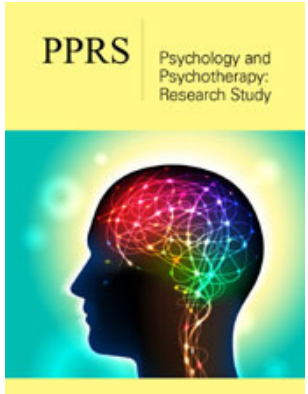

*Corresponding author: Benali A, Department of Psychiatry, Morocco

Submission: 衉July 03, 2020

Published: 悳July 15, 2020

Volume 4 - Issue 1

How to cite this article: Benali A, Chichou H. Students Perceptions of the Educational Environment: A Cross-Sectional Study from a Moroccan Medical University. Psychol Psychother Res Stud. 4(1). PPRS. 000576. 2020.

DOI: 10.31031/PPRS.2020.04.000576

Copyright@ Benali A, This article is distributed under the terms of the Creative Commons Attribution 4.0 International License, which permits unrestricted use and redistribution provided that the original author and source are credited.

\section{Benali $A^{*}$ and Chichou $\mathrm{H}$}

Department of Psychiatry, Morocco

\begin{abstract}
Introduction: The quality of the educational environment has frequently been identified as crucial to effective learning.
\end{abstract}

Purpose: To evaluate student's perceptions on the educational environment and to identify the effect of gender, year of study and age on students' perceptions of their educational environment.

Method: This was a cross-sectional descriptive and analytical study, using the DREEM questionnaire, with 380 students from the Faculty of Medicine and Pharmacy of Marrakech $\left(3^{\text {rd }}, 4^{\text {th }}, 5^{\text {th }}, 6^{\text {th }}, 7^{\text {th }}\right.$ and $8^{\text {th }}$ year), during the academic year 2017- 2018.

Result: We recruited 358 students in a period of 2 weeks (from 15/01/2018 to 30/01/2018), achieving a response rate of $94.2 \%$. There was a predominance of females (66.48\%). The mean age was $22.20 \pm 2.149$ years. The mean total score of DREEM was $86.5 \pm 29.194$ which indicates the existence of several significant problems. Among the 50 items of the DREEM score, we noted 35 areas of concern (Score $\leq 2)$, and item 3 «There is a good support system for students when they experience stress" had the lowest score. The factors associated with a poor perception of the educational environment are the female gender and the age $>21$ years. The wish and the recommendation of medical studies were associated to a good perception of the educational environment.

Conclusion: In this study, students perceived the educational environment as having many problems. The findings of this study were useful to identify areas in need of improvement.

\section{Introduction}

Curriculum is considered to be the most holistic, inclusive and comprehensive entity and notion in education. This aspect of holism and comprehensiveness leads one to define curriculum as everything that is happening in the classroom, department, faculty, medical school or the university as a whole [1]. Educational environment is one of the most important determinants of an effective curriculum. There is a proven connection between the environment and the valuable outcomes of students' achievement, satisfaction and success Roff et al. [2]. Developed the Dundee Ready Education Environment Measure (DREEM), an international, culturally non-specific, generic instrument that provides global readings and diagnostic analyses of undergraduate educational environments within health professions institutions. It generates a profile of a particular institution's environmental strengths and weaknesses [2]. Each year thousands of doctor's graduates from Moroccan medical faculties. As these students enter their professions, their level of competence is not only a reflection of the educational institution they attended; it is of the utmost importance to all their future patients and the broader community generally. An important component of academic strengthening and curricula renewal is the evaluation of the quality and structure of health science programs. After all, it has been suggested that a positive learning environment as a 
student can lead to increased satisfaction, achievement and success as a practitioner post-graduation [3,4]. A motivating learning environment fosters deep self-directed learning in the student and subsequently good medical practice in the physician. Consequently, demotivating elements such as perceived bias, poor role models, information overload, teacher centered, or disorganized teaching need to be identified and eliminated [5]. Therefore, the aim of this study is to evaluate students' perceptions, recorded on the DREEM inventory, of the overall education environment as well as specific aspects of this learning environment. A second aim of this study is to investigate whether the education environment or aspects of it are perceived more or less favorably for students of different year levels, age or gender.

\section{Material and Methods}

\section{Instrument}

The Dundee Ready Education Environment Measure (DREEM) is a questionnaire developed by Roff et al. [2] to measure the educational environment in health professional education programs. The questionnaire was developed using a Delphi approach involving a range of professional health educators in different settings and countries. The DREEM contains 50 statements. Each statement is assessed using a 5-point Likert scale ranging from strongly agree to strongly disagree.

Items are scored as follows:

Strongly disagree $(0)$

Disagree (1)

Uncertain (2)

Agree (3)

Strongly agree (4)

However, nine of the 50 items $(4,8,9,17,25,35,39,48$ and 50) are negative statements and are reverse scored. The 50item DREEM has a maximum score of 200 indicating the ideal educational environment.

It is also divided into five subscales:

1. Students' perceptions of learning (12 items, max score 48)

2. Students' perceptions of teachers (11 items, max score 44)

3. Students' academic self-perceptions (8 items, max score 32)

4. Students' perception of atmosphere (12 items, max score 48)

5. Students' social self-perceptions (7 items, max score 28)

The DREEM can be used to pinpoint more specific strengths and weaknesses. Items with mean scores $\geq 3.5$ are considered as highly positive points. Items with mean scores between 2 and 3 indicate aspects of the environment that could be improved. While items with a mean of 2 or less should be examined more closely as they indicate problem areas.

\section{Subjects and settings}

This cross-sectional study was conducted in the Faculty of Medicine and Pharmacy of Marrakech in January 2018. The questionnaire was distributed to clinical stage medical students $\left(3^{\text {rd }}, 4^{\text {th }}, 5^{\text {th }}\right.$ and $6^{\text {th }}$ years $)$ in the University Hospital Mohammed VI of Marrakech, several sessions were organized within many hospital departments to explain the interest and purpose of the study. Then, the students, having accepted to participate in the survey, received the questionnaires to fill, while respecting their anonymity. These questionnaires, once completed, were given to the secretaries of each service. The students of the $7^{\text {th }}$ and the $8^{\text {th }}$ year received for their part the questionnaire directly within the faculty of Medicine and Pharmacy of Marrakech. Given the personal nature of certain questions in this survey, the questionnaire was also made available in electronic format in order to respect the privacy of students and to promote their sincerity.

\section{Statistical analysis}

The Data were analyzed using Excel 2010 and the statistical analyzes were performed by the ANOVA test. A P-value $<0.05$ served as the cut-off value for statistical significance.

\section{Result}

The response rate was $94.2 \%$ (total 358 out of 380 students). Among the 358 students, $120(33.52 \%)$ were male and 238(66.48\%) were female. The mean age of participants was 22.2(SD 2.149) years. Considering year of study, there were 93(25.98\%) third year, $90(25.14 \%)$ fourth year, $82(22.91 \%)$ fifth year, 53(14.8\%) sixth year, $8(2.23 \%)$ seventh year and $32(8.94 \%)$ eighth year students. $279(77.93 \%)$ students chose to study medicine, and 207(57.82\%) wouldn't recommend medical studies to their friends. The mean DREEM total score was 86.5(SD 29.194). Total DREEM scores ranged from 11 to 185 . The descriptive statistics for each of the five DREEM subscales are presented in Table 1. The highest score was found in the subscale of students' perceptions of teachers $(21.71 / 44(49.3 \%))$, and the lowest score was found in the subscale of students' perceptions of learning (17.38/48 (36.2\%)).

Table 1 shows the individual item analysis of DREEM according to the five different subscales. 35 items scored less than two. Among them, 12 items were from the students' perceptions of learning subscale, four items were from the students' perceptions of teachers subscale, four items were from the students' academic self-perceptions subscale, 11 items were from the students' perceptions of atmosphere subscale and four items were from the students' social self-perceptions. The remaining 15 items scored between 2 and 3; there was no area of excellence (Item score $\geq 3.5$ ). The lowest score was 0.57 for Item 3 "There is a good support system for students who get stressed". 
Table 1: Individual item analysis for each subscale of DREEM.

\begin{tabular}{|c|c|c|c|}
\hline & Items & Mean & SD \\
\hline \multicolumn{4}{|c|}{ Students' Perception of Learning (Spol) } \\
\hline 1 & I am encouraged to participate during teaching sessions & 1,47 & 1,33 \\
\hline 7 & The teaching is often stimulating & 1,23 & 1,21 \\
\hline 13 & The teaching is student-centered & 1,32 & 1,18 \\
\hline 16 & The teaching helps to develop my competence & 1,85 & 1,19 \\
\hline 20 & The teaching is well-focused & 1,52 & 1,13 \\
\hline 22 & The teaching helps to develop my confidence & 1,33 & 1,28 \\
\hline 24 & The teaching time is put to good use & 1,3 & 1,29 \\
\hline 25 & The teaching over-emphasizes factual learning & 1,2 & 1,12 \\
\hline 38 & I'm clear about the learning objectives of the course & 1,57 & 1,23 \\
\hline 44 & The teaching encourages me to be an active learner & 1,56 & 1,24 \\
\hline 47 & Long-term learning is emphasized over short-term learning & 1,52 & 1,2 \\
\hline 48 & The teaching is too teacher-centered & 1,5 & 1,26 \\
\hline Total mean score & & 17.38 & 8.063 \\
\hline Maximum score & & 48 & \\
\hline \multicolumn{4}{|c|}{ Students' Perception of Teachers (Spot) } \\
\hline 2 & The teachers are knowledgeable & 2,55 & 1,04 \\
\hline 6 & The teachers adopt a patient-centered approach to consulting & 2,22 & 1,18 \\
\hline 8 & The teachers ridicule the students & 1,56 & 1,27 \\
\hline 9 & The teachers are authoritarian & 1,22 & 1,15 \\
\hline 18 & The teachers have good communication skills with patients & 2,3 & 1,08 \\
\hline 29 & The teachers are good at providing feedback to students & 1,5 & 1,15 \\
\hline 32 & The teachers provide constructive criticism here & 1,79 & 1,27 \\
\hline 37 & The teachers give clear examples & 2,07 & 1,23 \\
\hline 39 & The teachers get angry in teaching & 2,12 & 1,27 \\
\hline 40 & The teachers are well-prepared for their teaching sessions & 2,03 & 1,21 \\
\hline 50 & The students irritate the teachers & 2,38 & 1,22 \\
\hline Total mean score & & 21.71 & 7.431 \\
\hline Maximum score & & 44 & \\
\hline \multicolumn{4}{|c|}{ Students' academic self-perception (SASP) } \\
\hline 5 & $\begin{array}{l}\text { Learning strategies that worked for me before continue to work for me } \\
\text { now }\end{array}$ & 2,06 & 1,28 \\
\hline 10 & I am confident about my passing this year & 2,18 & 1,32 \\
\hline 21 & I feel I am being well prepared for my profession & 1,31 & 1,13 \\
\hline 26 & Last year's work has been a good preparation for this year's work & 1,81 & 1,24 \\
\hline 27 & I am able to memorize all I need & 2,16 & 1,3 \\
\hline 31 & I have learnt a lot about empathy in my profession & 2,1 & 1,23 \\
\hline 41 & My problem-solving skills are being well developed here & 1,26 & 1,13 \\
\hline 45 & Much of what I have to learn seems relevant to a career in healthcare & 1,89 & 1,27 \\
\hline Total mean score & & 14.76 & 5.809 \\
\hline Maximum score & & 32 & \\
\hline \multicolumn{4}{|c|}{ Students' Perception of Atmosphere (Spoa) } \\
\hline 11 & The atmosphere is relaxed during ward teaching & 1,43 & 1,15 \\
\hline 12 & This school is well time-tabled & 1,47 & 1,31 \\
\hline 17 & Cheating is a problem in this school & 2,56 & 1,35 \\
\hline 23 & The atmosphere is relaxed during lectures & 1,82 & 1,16 \\
\hline 30 & There are opportunities for me to develop my interpersonal skills & 1,77 & 1,18 \\
\hline
\end{tabular}




\begin{tabular}{|c|c|c|c|}
\hline 33 & I feel comfortable in class socially & 1,9 & 1,33 \\
\hline 34 & The atmosphere is relaxed during class/seminars/tutorials & 1,84 & 1,18 \\
\hline 35 & I find the experience disappointing & 1,51 & 1,25 \\
\hline 36 & I am able to concentrate well & 1,93 & 1,23 \\
\hline 42 & The enjoyment outweighs the stress of the course & 1,44 & 1,16 \\
\hline 43 & The atmosphere motivates me as a learner & 1,28 & 1,13 \\
\hline 49 & I feel able to ask the questions I want & 1,63 & 1,34 \\
\hline Total mean score & & 20.58 & 8.11 \\
\hline Maximum score & & 48 & \\
\hline \multicolumn{4}{|c|}{ Students' social self-perception (SSSP) } \\
\hline 3 & There is a good support system for students who get stressed & 0,57 & 0,4 \\
\hline 4 & I am too tired to enjoy the course & 2 & 1,35 \\
\hline 14 & I am rarely bored in this course & 1,28 & 1,25 \\
\hline 15 & I have good friends in this course & 2,9 & 1,25 \\
\hline 19 & My social life is good & 2,11 & 1,4 \\
\hline 28 & I seldom feel lonely & 1,69 & 1,45 \\
\hline 46 & My accommodation is pleasant & 1,47 & 1,2 \\
\hline Total mean score & & 11.98 & 4.566 \\
\hline Maximum score & & 28 & \\
\hline
\end{tabular}

SPoL: students' perceptions of learning

SPoT: students' perceptions of teachers

SASP: students' academic self-perceptions

SPoA: students' perceptions of atmosphere

SSSP: students' social self-perceptions.

\section{Gender}

Total DREEM score and sub-scale scores were derived for males and females separately; males consistently reported higher scores than female students across all disciplines Table 2. However, there was a significant difference only in two subscales, students' academic self-perception $(\mathrm{p}=0.04)$ and students' social self-perception $(p=0.03)$. There were four individual items with statistically significant mean scores between male and female students Table 3 . Male students' scores were significantly higher than male students' scores in three of the four items listed.

Table 2: The total DREEM score and its components among female and male students.

\begin{tabular}{|c|c|c|c|}
\hline Components of Assessment & Male (mean; SD) & Female (mean; SD) & P value \\
\hline DREEM overall score & $89,22 \pm 31,658$ & $87,05 \pm 26,339$ & 0.697 \\
\hline Perception of learning score & $19,13 \pm 8,602$ & $18,52 \pm 6,89$ & 0.558 \\
\hline Perception of teachers score & $21,32 \pm 8,196$ & $21,91 \pm 7,023$ & 0.548 \\
\hline Academic self-perception score & $15,55 \pm 6,114$ & $14,36 \pm 5,619$ & 0.04 \\
\hline Perception of atmosphere score & $20,45 \pm 8,734$ & $20,65 \pm 7,794$ & 0.442 \\
\hline Social self-perception score & $12,75 \pm 4,668$ & $11,6 \pm 4,474$ & 0.03 \\
\hline
\end{tabular}

Table 3: Statistically significant differences between male and female students.

\begin{tabular}{|c|c|c|c|}
\hline & Item & Male & Female value \\
\hline 22 & The teaching helps to develop my confidence & 1,53 & 1,22 \\
\hline 23 & The atmosphere is relaxed during lectures & 1,73 & 1,86 \\
\hline 27 & I am able to memorize all I need & 2,56 & 1,94 \\
\hline 41 & My problem-solving skills are being well & 1,01 & 1,18 \\
\hline
\end{tabular}


Age

There was a significant difference between age and the global DREEM and 3 DREEM subscales scores, with students younger than
21 having more positive perceptions of their learning environment than older students Table 4. Statistically significant relationships were observed between age and 7 individual items Table 5 .

Table 4: The comparison of the total DREEM score and its components by age.

\begin{tabular}{|c|c|c|c|}
\hline \multirow{2}{*}{ Components of Assessment } & \multicolumn{2}{|c|}{ Age } & \multirow{2}{*}{$P$ value } \\
\hline & 19-21 years & 22-32 years & \\
\hline DREEM overall score & $93,05 \pm 25,293$ & $82,73 \pm 29,947$ & 0.021 \\
\hline Perception of learning score & $19,89 \pm 6,764$ & $17,61 \pm 8,005$ & 0.05 \\
\hline Perception of teachers score & $23,4 \pm 6,869$ & $20,1 \pm 7,608$ & 0.0002 \\
\hline Academic self-perception score & $15,68 \pm 5,371$ & $13,87 \pm 6,084$ & 0.003 \\
\hline Perception of atmosphere score & $21,77 \pm 7,498$ & $19,44 \pm 8,520$ & 0.01 \\
\hline Social self-perception score & $12,3 \pm 4,379$ & $11,68 \pm 4,731$ & 0.448 \\
\hline
\end{tabular}

Table 5: Statistically significant differences according to age.

\begin{tabular}{|c|c|c|c|c|}
\hline \multirow{2}{*}{} & \multirow{2}{*}{ Item } & \multicolumn{2}{|c|}{ Age } & \multirow{2}{*}{ P value } \\
\cline { 3 - 5 } & & $\mathbf{1 9 - 2 1}$ years & $\mathbf{2 2 - 3 2}$ years \\
\hline 2 & The teachers are knowledgeable & 2,6 & 2,49 & 0,04 \\
\hline 29 & The teachers have good communication skills with patients & 2,5 & 2,09 & 0,006 \\
\hline 32 & The teachers are good at providing feedback to students & 1,7 & 1,28 & 0,04 \\
\hline 40 & The teachers provide constructive criticism here & 2,02 & 1,55 & 0,001 \\
\hline 44 & The teachers are well-prepared for their teaching sessions & 2,26 & 1,8 & 0,02 \\
\hline 35 & The teaching encourages me to be an active learner & 1,8 & 1,33 & 0,005 \\
\hline
\end{tabular}

\section{Year of study}

Total DREEM score and sub-scale scores were derived for students in different years of study and summarized in Table 6. In general there appeared to be a slight reduction in scores with progression through the course of study, and the ANOVA conducted on the total and the subscales DREEM scores found Year of Study to be significantly associated with only one subscale, students' perceptions of teachers $(\mathrm{p}=0.0005)$. Statistically significant year level differences were also noted for 11 items Table 7.

Table 6: The comparison of the total DREEM score and its components by year of study.

\begin{tabular}{|c|c|c|c|c|c|c|c|}
\hline Year & $\mathbf{n}$ & Dreem Overall Score & SPoL & SPoT & SASP & SPoA & SSSP \\
\hline 3rd year & 93 & $90,05 \pm 23,981$ & $19,08 \pm 6,354$ & $23,07 \pm 6,748$ & $15,34 \pm 5,711$ & $20,59 \pm 7,052$ & $11,95 \pm 3,939$ \\
\hline 4th year & 90 & $88,82 \pm 25,062$ & $18,97 \pm 7,262$ & $22,15 \pm 6,409$ & $14,87 \pm 5,209$ & $20,87 \pm 7,475$ & $11,93 \pm 4,819$ \\
\hline 5th year & 82 & $92,69 \pm 31,948$ & $19,65 \pm 8,227$ & $22,97 \pm 7,925$ & $15,28 \pm 5,888$ & $21,74 \pm 9,278$ & $13,03 \pm 5,119$ \\
\hline 6th year & 53 & $77,66 \pm 30,955$ & $17,03 \pm 8,781$ & $18,3 \pm 8,03$ & $13,67 \pm 6,594$ & $18,28 \pm 8,265$ & $10,35 \pm 4,071$ \\
\hline 7th year & 8 & $68,12 \pm 21,276$ & $14,25 \pm 4,862$ & $15,625 \pm 5,578$ & $11,62 \pm 2,615$ & $18,87 \pm 6,289$ & $10,75 \pm 4,743$ \\
\hline 8th year & 32 & $87,34 \pm 30,318$ & $18,53 \pm 7,228$ & $20,5 \pm 7,886$ & $14 \pm 6,475$ & $21,75 \pm 8,994$ & $12,56 \pm 4,226$ \\
\hline p value & & 0,05 & 0,21 & 0,0005 & 0,208 & 0,12 & 0,069 \\
\hline
\end{tabular}

Table 7: Statistically significant differences according to age.

\begin{tabular}{|c|c|c|c|c|c|c|c|c|}
\hline & \multirow{2}{*}{ Item } & \multicolumn{6}{|c|}{ Year } & \multirow{2}{*}{$P$ value } \\
\hline & & $3^{\text {rd }}$ year & $4^{\text {th }}$ year & $5^{\text {th }}$ year & $6^{\text {th }}$ year & $7^{\text {th }}$ year & $8^{\text {th }}$ year & \\
\hline 2 & The teachers are knowledgeable & 2,55 & 2,54 & 2,79 & 2,3 & 2 & 2,43 & 0,007 \\
\hline 12 & The teaching helps to develop my competence & 1,16 & 1,4 & 1,54 & 1,62 & 0,87 & 2,25 & 0,003 \\
\hline 15 & I have good friends in this course & 3,13 & 2,57 & 3,26 & 2,43 & 2,87 & 2,93 & 0,003 \\
\hline 18 & $\begin{array}{c}\text { The teachers have good communication skills } \\
\text { with patients }\end{array}$ & 2,59 & 2,33 & 2,35 & 1,98 & 1,37 & 1,96 & 0,01 \\
\hline 24 & The teaching time is put to good use & 1,1 & 1,14 & 1,35 & 1,37 & 1,5 & 1,93 & 0,04 \\
\hline 28 & I seldom feel lonely & 1,72 & 1,71 & 1,97 & 1,16 & 1,37 & 1,75 & 0,04 \\
\hline
\end{tabular}




\begin{tabular}{|c|c|c|c|c|c|c|c|c|}
\hline 30 & $\begin{array}{l}\text { There are opportunities for me to develop my } \\
\text { interpersonal skills }\end{array}$ & 1,83 & 1,8 & 1,96 & 1,28 & 0,75 & 2,06 & 0,04 \\
\hline 32 & The teachers provide constructive criticism here & 2,04 & 1,73 & 1,96 & 1,24 & 0,75 & 1,9 & 0,003 \\
\hline 37 & The teachers give clear examples & 2,29 & 2,18 & 2,04 & 1,69 & 1,12 & 2,06 & 0,03 \\
\hline 40 & $\begin{array}{l}\text { The teachers are well-prepared for their teaching } \\
\text { sessions }\end{array}$ & 2,23 & 2,17 & 2,04 & 1,73 & 1,25 & 1,65 & 0,04 \\
\hline 46 & My accommodation is pleasant & 1,2 & 1,55 & 1,5 & 1,5 & 1,12 & 2 & 0,005 \\
\hline
\end{tabular}

\section{Discussion}

The high response rate (94.2\%) obtained in our study was due to the brief introduction given to students about the aim of this study, which convince them that the results of such a study would lead to significant changes in their learning. The students also perceived it as an ideal opportunity to express their opinions.

The response rate in other similar studies ranged from $44.6 \%$ to $96.9 \%$. This showed that our response rate was among the highest, indicating that our students were keen to participate in such study to improve their school. This response rate is comparable to that obtained in Canada (91\%) [3] and in Australia (90\%) [6]. On the other hand, the lowest response rate obtained in King Saud University (44.6\%) was explained by students' fears of participation in their study and its impact on their exam results [7]. A study in Singapore reported that 79 (80.6\%) of the 98 studies which reported DREEM scores showed total DREEM scores between 100 and 150, and only 3 studies reported excellent scores between 150 and 200 [8]. The global DREEM score of 86.5/200 indicated the existence of many significant problems in the educational environment. As far as we can verify, our study had the lowest score reported among published studies using the relatively recently validated DREEM inventory. The highest score was reported in Turkey and was of 156.91 [9]. This cry from students is, unfortunately, only too common to medical and many other healthcare programs due in no small part to the quantity and quality of information that has to be absorbed during the time of studies.

The local studies, that used DREEM, showed fairly similar results: 90.5/200 in the Faculty of Medicine and Pharmacy of Rabat [10] and 99.2/200 in the Faculty of Medicine and Pharmacy of Fes [11]. Internationally, overall DREEM scores reported were 89.9/200 in Saudi Arabia [7], 94.65/200 in South Korea [12], 108.5/200 in Brazil [13], 117.2/200 in Peru [14], 131.1/200 in Thailand [15] and $135.44 / 200$ in Mexico [16]. Among the subscale scores, students' perception of learning was lowest in our study (36.2\%). This is very close to the score of $38.3 \%$ reported by Andalib [17] and of $39.58 \%$ reported by Till [3], but lower than the score of $71.7 \%(34.42 / 48)$ [18] reported by Vaughan [6]; Table 8.

Table 8: Comparison of DREEM scores at the faculty of medicine of marrakech and other studies.

\begin{tabular}{|c|c|c|c|c|c|c|c|}
\hline Year & Country [reference] & Overall Mean Score & SPoL & SPoT & SASP & SPoA & SSSP \\
\hline 2018 & Morocco [Our study] & 86,5 & 17,38 & 21,71 & 14,76 & 20,58 & 11,98 \\
\hline 2008 & Saudi Arabia [7] & 89,9 & 19,5 & 21,2 & 14,8 & 21,3 & 13 \\
\hline 2014 & Morocco [10] & 90,8 & 21,2 & 21,8 & 13,1 & 19 & 15,6 \\
\hline 2016 & South Korea [12] & 94,65 & 20,2 & 23,03 & 16,16 & 21,7 & 13,57 \\
\hline 2015 & Iran [17] & 95,8 & 18,4 & 26,2 & 13,6 & 23,5 & 13,8 \\
\hline 2014 & Morocco [11] & 99,2 & 22 & 24,31 & 16,84 & 23,36 & 13,71 \\
\hline 2017 & Peru [14] & 117,2 & 26,5 & 27,5 & 21 & 26,6 & 15,6 \\
\hline 2018 & Thailand [15] & 131,1 & 31,4 & 30,7 & 21,4 & 29,8 & 17,7 \\
\hline 2016 & China [18] & 134,82 & 31,68 & 20,45 & 32,72 & 32,04 & 17,93 \\
\hline 2017 & Mexico [16] & 135,44 & 34,06 & 28,47 & 23,64 & 31,92 & 17,36 \\
\hline
\end{tabular}

The perception of learning atmosphere, which other studies showed to have significant impact on students' behavior, academic progress, and sense of well-being, scored low in the present study. The students appear unable to concentrate, memorize or enjoy the courses while the atmosphere is not relaxed during lectures or trainings. Many studies reported generally similar findings $[7,19,20]$. Medical students everywhere seem to share similar concerns as reported in studies that utilized the DREEM instrument $[21,22]$. It is interesting that most areas of concern are related to what is taught rather than how it is taught and allude to the curriculum content rather than its delivery. There were 35 items that scored below 2, which indicated problematic areas of the learning environment. Item 3 (There is a good support system for students who get stressed) had the lowest score (0.57) in the questionnaire. This item also scored the lowest in other studies $[19,23]$. A study in Greece [23] found 19 problem areas, another study in Germany [24-26] reported 18 items with scores below 2, while a study in Iran [27] objectified the existence of 22 problem areas.

In our study, no area of excellence (Score $\geq 3.5$ ) was reported, which is in agreement with many studies. [24,28-33]. This study revealed significantly higher scores for males in ASP and SSP, for students younger than 22 years old for PoT, ASP and PoA and for 
junior classes for ASP. Some studies found a statistically significant difference between genders, with females in general, being more critical concerning the quality of teaching and general climate of the school $[21,34]$ which is in agreement with the present study. Others, however, reported that mean total score for males were less than females students [5,35-39]. In general, it appears that gender is not associated with a consistent pattern of perception of educational environment although there is a longstanding evidence that males and females typically exhibit different learning styles [40]. Male students had a more positive perception about the role of the faculty in building their self-confidence, developing students' problem-solving skills and their learning ability.

These findings were concordant with the results reported in Saudi Arabia [19]. On the other hand, female students had a more positive perception of the atmosphere during classes, which coincides with the results obtained in Sri Lanka [41]. The perception of environment, in this study, varied between levels of enrolment. This result is in agreement with an English study that showed that perceptions of the educational environment, learning, teachers and of atmosphere were significantly superior for first year students over second year students [42]. However, a local study reported significantly higher scores in SSP for students in their fifth year of study than those in their fourth year [10]. This cry from students is, unfortunately, only too common to medical students and many other healthcare professions programs, due in no small part to the quantity and the quality of information that has to be absorbed during the time of studies.

\section{Conclusion}

The DREEM questionnaire has been useful in identifying the strengths and the major defects of the educational environment in our faculty. The problematic areas are clear indications of where the priorities for reform should take place at the study site. A larger study may need to be undertaken to verify the above results and conclusions, and more importance should be given to the students perception of the learning environment, as it can be used to initiate change and improvement.

\section{References}

1. Genn JM (2001) AMEE Medical Education Guide No. 23 (Part 1): Curriculum, environment, climate, quality and change in medical education-a unifying perspective. Med Teach 23(4): 337- 344.

2. Roff S, McAleer S, Harden RM, Al-Qahtani M, Ahmed AU, et al. (1997) Development and validation of the Dundee Ready Education Environment Measure (DREEM). Medical Teacher 19(4): 295-299.

3. Till $\mathrm{H}$ (2004) Identifying the perceived weaknesses of a new curriculum by means of the Dundee Ready Education Environment Measure (DREEM) Inventory. Med Teach 26(1): 39-45.

4. Entwistle N, Ramsden P (1983) Understanding Student Learning. 32: 266.

5. Al-Kabbaa AF, Ahmad HH, Saeed AA, Abdalla AM, Mustafa AA (2012) Perception of the learning environment by students in a new medical school in Saudi Arabia: Areas of concern. Journal of Taibah University Medical Sciences 7(2): 69-75.

6. Vaughan B, Carter A, Macfarlane C, Morrison T (2014) The DREEM, part 1: Measurement of the educational environment in an osteopathy teaching program. BMC Medical Education 14: 99.
7. Al Ayed IH, Sheik SA (2008) Assessment of the educational environment at the College of Medicine of King Saud University, Riyadh. East. Mediterr. Health J 14(4): 953-959.

8. Chan CYW, Sum MY, Tan GMY, Tor PC, Sim K (2018) Adoption and correlates of the Dundee Ready Educational Environment Measure (DREEM) in the evaluation of undergraduate learning environments-A systematic review. Med Teach 40(12):1240-1247.

9. ALCI B (2009) Perceptions of students of Yeditepe university faculty of medicine about educational environment. the New Journal of Medicine 26: 205-209.

10. Belayachi J, Razine R, Boufars A, Saadi A, Madani N, et al. (2015) Moroccan medical students' perceptions of their educational environment. J Educ Eval Health Prof 12: 47

11. Chaouche M (2014) The mental health and educational environment of medical students in Fez. Thesis of Medicine Fez p. 152.

12. Kim H, Jeong H, Jeon P, Kim S, Park YB, et al. (2016) Perception study of traditional Korean medical students on the medical education using the dundee ready educational environment measure. Evidence-Based Complementary and Alternative Medicine 1-7.

13. Nucci VGK, Pinto CA, Maria A (2017) Perception of the educational environment (ee) and common mental disorders (cmd) among medical students from a Brazilian institution. International Journal of Development Research 7(9): 15104-15109.

14. Flores O, Aurazo LY, Morales ZA, Rondán PL, Soto LF, et al. (2017) Psychometric analysis of a questionnaire to measure the educational environment in a sample of medical students in Peru. Rev Peru Med Exp Salud Publica 34(2): 255-260.

15. Hongkan W, Arora R, Muenpa R, Chamnan P (2018) Perception of educational environment among medical students in Thailand. Int J Med Educ 9: 18-23.

16. Barojas AS, Sastré JA, Orueta CML (2017) Validation of the Spanish translation of the Dundee Ready Education Environment Measure. Inv Ed Méd 9(1).

17. Andalib MM, Malekzadeh MM, Agharahimi Z, Daryabeigi M, Yaghmaei B, et al. (2015) Evaluation of educational environment for medical students of a tertiary pediatric hospital in Tehran, using dreem questionnaire. Iran J Pediatr 25(5): e2362.

18. Xu X, Wu D, Zhao X, Chen J, Xia J, et al. (2016) Relation of perceptions of educational environment with mindfulness among Chinese medical students: a longitudinal study. Medical Education Online 21(1):30664.

19. Al-Hazimi A, Zaini R, Al-Hyiani A, Hassan N, Gunaid A, et al. (2004) Educational environment in traditional and innovative medical schools: A study in four undergraduate medical schools. Educ Health (Abingdon) 17(2): 192-203

20. Roff S, McAleer S (2001) What is educational climate? Med Teach 23(4): 333-334.

21. Mayya S, RoffS (2004) Students' perceptions of educational environment: A comparison of academic achievers and under-achievers at kasturba medical college, India. Educ Health (Abingdon) 17(3): 280-291.

22. Harden RMJC (2000) AMEE Guide No 20: The good teacher is more than a lecturer - the twelve roles of the teacher. Medical Teacher 22(4): 334-347.

23. Dimoliatis IDK, Vasilaki E, Anastassopoulos P, Ioannidis JPA, Roff S (2010) Validation of the Greek translation of the Dundee Ready Education Environment Measure (DREEM). Educ Health (Abingdon) 23(1): 348.

24. Rotthoff T, Ostapczuk MS, De Bruin J, Decking U, Schneider M, et al. (2011) Assessing the learning environment of a faculty: Psychometric validation of the German version of the Dundee Ready Education Environment Measure with students and teachers. Med Teach 33(11): e624-636. 
25. Roff S, McAleer S, Ifere OS, Bhattacharya S (2001) A global diagnostic tool for measuring educational environment: comparing Nigeria and Nepal. Medical Teacher 23(4): 378-382.

26. Herrera C, Padilla OP (2015) Análisis psicométrico del cuestionario DREEM para medirel ambiente de aprendizaje en Chile. Rev Educ Cienc Salud 12(2): 134-141.

27. Aghamolaei T, Fazel I (2010) Medical students' perceptions of the educational environment at an Iranian Medical Sciences University. BMC Medical Education 10: 87.

28. Al Sheikh MH (2014) Educational environment measurement, how is it affected by educational strategy in a Saudi medical school? A multivariate analysis. Journal of Taibah University Medical Sciences 9(2): 115-122.

29. Al-Qahtani MF (2015) Associations between approaches to study, the learning environment, and academic achievement. Journal of Taibah University Medical Sciences 10(1): 56-65.

30. Veerapen K, McAleer S (2010) Students' perception of the learning environment in a distributed medical programme. Med Educ Online $\mathrm{p}$. 15.

31. Tontus O (2010) DREEM: Dreams of the Educational Environment as its effect on education result of 11 medical faculties of Turkey. Clin Med 27: 104-108.

32. Shehnaz SI, Sreedharan J (2011) Students' perceptions of educational environment in a medical school experiencing curricular transition in United Arab Emirates. Med Teach 33(1): e37-e42.

33. Bennett D, Kelly M, O Flynn S (2010) Are the bigger hospitals better: DREEM on? Ir J Med Sci 179(4): 515-519.

34. Bouhaimed M, Thalib L, Doi SAR (2009) Perception of the educational environment by medical students undergoing a curricular transition in Kuwait. Med Princ Pract 18(3): 204-208.
35. Ugusman A, Othman NA, Razak ZNA, Soh MM, Faizul PNK, et al. (2015) Assessment of learning environment among the first-year Malaysian medical students. Journal of Taibah University Medical Sciences 10(4): 454-460.

36. Makhdoom NM (2009) Assessment of the quality of educational climate during undergraduate clinical teaching years in the college of medicine, Taibah University. Journal of Taibah University Medical Sciences 4(1): 42-52.

37. Dunne F, McAleer S, Roff S (2006) Assessment of the undergraduate medical education environment in a large UK medical school. Health Education Journal 65(2): 149-158.

38. Brown T, Williams B, Lynch M (2011) The Australian DREEM: Evaluating student perceptions of academic learning environments within eight health science courses. International Journal of Medical Education 2: 94-101.

39. Farajpour A, Raisolsadat SMA, Moghadam SS, Mostafavian Z (2017) Perception of educational environment among undergraduate students of health disciplines in an Iranian university. Int J Med Educ 8: 300-306.

40. Philbin M, Meier E, Huffman S, Boverie P (1995) A survey of gender and learning styles. Sex Roles 32(7-8): 485-494.

41. Jiffry MTM, McAleer S, Fernando S, Marasinghe RB (2005) Using the DREEM questionnaire to gather baseline information on an evolving medical school in Sri Lanka. Med Teach 27(4): 348-352.

42. Ousey K, Stephenson J, Brown T, Garside J (2014) Investigating perceptions of the academic educational environment across six undergraduate health care courses in the United Kingdom. Nurse Education in Practice 14(1): 24-29. 